\title{
Groundwater vulnerability study using SINTACS method in Banguntapan district, Bantul Regency
}

\author{
Kartika Ayu Wandari ${ }^{1}$, Ignasius Loyola Setyawan Purnama ${ }^{1, *}$, and Vincentia Anindha Primacintya ${ }^{2}$ \\ ${ }^{1}$ Faculty of Geography, Universitas Gadjah Mada, Yogyakarta, Indonesia \\ ${ }^{2}$ Accounting Programme, Master of Science and Doctoral, Faculty of Economics and Business, Universitas Gadjah Mada, Indonesia
}

\begin{abstract}
As one of the districts in Bantul Regency which borders directly with the City of Yogyakarta, the District of Banguntapan has the potential to be an area affected by city development. This is what drives population growth in this district, so that the waste it generates also increases. The purpose of this study is to determine the level of groundwater vulnerability to pollution by using the SINTACS method and analyzing the dominant factors that influence it. Calculation and analysis results show that the variation of groundwater vulnerability index values in the study area ranged from 182.8 to 200.3 , with 10 locations classified as high vulnerability and 2 locations classified as rather high vulnerability. Because it is located in a similar geological condition, namely the Aquifer Unit of Merapi Volcanic Fluvio Plain where most of the constituent material of this aquifer is sand and a little clay as inserts, the difference in groundwater vulnerability to pollution in the study area is only determined by the difference in groundwater depth.
\end{abstract}

\section{Introduction}

In general, urban areas have a large population, which encourages the need for large clean water as well. The large population will affect the sustainability of groundwater use. In order not to cause adverse impacts, groundwater utilization needs to pay attention to the environmental balance in order to be sustainable.

According to [1], in addition to increasing groundwater exploitation, population growth will also increase the amount of household and industrial waste that is known to have caused significant changes in groundwater quality. The decline in groundwater quality in an area indicates that groundwater pollution and land use are sources of contaminant release that have the opportunity to reduce groundwater quality through the infiltration process [2], while according to [3], sources of groundwater pollutants can be either point or nonpoints originating from domestic, agricultural, industrial, mining and tourism waste

One of the many approaches taken to maintain the sustainability of good water quality and quantity is to study groundwater vulnerability to pollution [4]. Potential groundwater pollution is influenced by the hydrogeological characteristics of an area. Hydrogeological characteristics are composed of several main geological and hydrological parameters as a system that allows the movement of water in the rock layer [5]. Different hydrogeological characteristics influence groundwater vulnerability to potential pollution. Groundwater vulnerability assessment on pollution is important to know the level of vulnerability and as a frame of reference in groundwater planning, development and management.
Basically, groundwater vulnerability is divided into two namely intrinsic and specific groundwater vulnerability. Intrinsic groundwater vulnerability refers to groundwater vulnerability to contaminants generated by human activities by taking into account geological, hydrological, and hydrogeological characteristics, while specific vulnerability refers to groundwater susceptibility to certain contaminants by considering the nature of contaminants and their relationship to various intrinsic vulnerability factors [6].

As one of the districts in Bantul Regency which borders directly with the City of Yogyakarta, the District of Banguntapan has the potential to be an area affected by city development. This is what drives population growth in the Banguntapan District. The increase in population is also driven by the development of tertiary education, such as STIKES Surya Global, STIE IEU, STTL, STTKD, STIMIK Amikom, BSI Health Polytechnic, Piri Technical Academy, and AMA Dharmala [7]. As a result, the need for land also increased. Increased land requirements cause land conversion, which affects groundwater related to changes in the hydrological response and its impact on groundwater quality.

Noting the existing problems and the increasing influence of human activities in this district, a groundwater vulnerability assessment is needed. The results of the study will be able to show priority areas for groundwater monitoring and protection [8]. The method used in this study is the SINTACS method. This method is one of the Point Count System Model (PCSM) index methods that uses a score system and weighting physical parameters to assess groundwater

* Corresponding author: Setyapurna@geo.ugm.ac.id 
vulnerability to pollution [9]. This method was chosen because it is more representative for groundwater vulnerability assessment and mapping on a small to medium scale.

\section{Method of research}

To analyze groundwater vulnerability to pollution in the study area, the SINTACS method is based on a numerical system of weights and ratings [10]. Weights are determined based on the significance of the effect of parameters on groundwater pollution, while the rating is determined based on the significance of the influence of the variables in each parameter on groundwater pollution. Ratings of each SINTACS parameter and variables in each parameter are shown in Tables 1, 2 and 3.

Table 1. Rating of Phreatic Depth, Infiltration and Aeration Condition [11-13]

\begin{tabular}{|c|c|c|c|l|c|}
\hline \multicolumn{2}{|c|}{ Depth of Phreatic $(\mathrm{m})$} & \multicolumn{2}{|c|}{ Infiltration (mm/hour) } & \multicolumn{2}{c|}{ Aeration Condition } \\
\hline Class & Rating & Class & Rating & Tipe of rock & Rating \\
\hline $0.0-2.0$ & 10.0 & $<1$ & 1.0 & Coarse alluvial sediment & $8-10$ \\
\hline $2.0-2.5$ & 9.0 & $1-5$ & 2.0 & Karst limestone & $4-8$ \\
\hline $2.5-3.5$ & 8.5 & $5-20$ & 3.0 & Fractured limestone & $2-5$ \\
\hline $3.5-4.5$ & 8.0 & $20-65$ & 4.0 & Silt dolomit & $3-6$ \\
\hline $4.5-5.0$ & 7.5 & $65-125$ & 5.0 & Fine-moderate alluvial sediment & $4-7$ \\
\hline $5.0-6.0$ & 7.0 & $125-250$ & 6.0 & Sand & $5-8$ \\
\hline $6.0-7.0$ & 6.5 & $>250$ & 7.0 & Sandstone, conglomerate & $2-5$ \\
\hline $7.0-8.0$ & 6.0 & & & Turbiditic sequences & $5-10$ \\
\hline $8.0-9.0$ & 5.5 & & & Silt volkanic & $1-3$ \\
\hline $9.0-10.0$ & 5.0 & & & Clarl, claystone & $1-2$ \\
\hline $10.0-13.0$ & 4.5 & & & Pyroklastic rock & $2-5$ \\
\hline $13.0-17.0$ & 4.0 & & & & $2-6$ \\
\hline $17.0-20.0$ & 3.5 & & & & \\
\hline $20.0-25.0$ & 3.0 & & & & \\
\hline $25.0-30.0$ & 2.5 & & & & \\
\hline $30,0-40,0$ & 2.0 & & & & \\
\hline$>40,0$ & 1.5 & & & & \\
\hline
\end{tabular}

Table 2. Rating of Soil Textur and Aquifer Media [11-13]

\begin{tabular}{|l|c|l|c|}
\hline \multicolumn{2}{|c|}{ Soil Textur } & \multicolumn{2}{c|}{ Aquifer Media } \\
\hline Textur & Rating & Type of Rock & Rating \\
\hline Clay & $1-1.5$ & Coarse alluvial sediment & $8-9$ \\
\hline Silty clay & $1.5-2.0$ & Karst limestone & $9-10$ \\
\hline Loamy clay & $2.0-3.0$ & Fractured limestone & $6-9$ \\
\hline Silty loam clay & $3.0-4.0$ & Silt dolomit & $4-7$ \\
\hline Loamy silt & $3.5-4.0$ & Fine-moderate alluvial sediment & $6-8$ \\
\hline Loam & $4.0-5.0$ & Sand & $7-9$ \\
\hline Sandy loam clay & $4.5-5.0$ & Sandstone, conglomerate & $4-9$ \\
\hline Sandy loam & $5.5-6.0$ & Turbiditic sequences & $5-8$ \\
\hline Sandy clay & $6.3-7.0$ & Slit volkanic & $8-10$ \\
\hline Peat & $7.5-8.0$ & Marl, claystone & $1-3$ \\
\hline Sandy silt & $8.0-8.5$ & Clay, silt, peat & $1-3$ \\
\hline Fine sand & $9.0-9.5$ & Pyroklastic rock & $4-8$ \\
\hline Fine gravel & $9.5-10.0$ & Silt metamorphose & $2-5$ \\
\hline Thin soil & 10.0 & & \\
\hline
\end{tabular}

Table 3. Rating of Hydraulic Conductivity and Gradient of Slope [11-13]

\begin{tabular}{|c|c|c|c|}
\hline Hydraulic Conductivity $(\mathrm{m} / \mathrm{sec})$ & \multicolumn{2}{|c|}{ Gradient of Slope (\%) } \\
\hline Value & Rating & Class & 9.5 \\
\hline $3.9 \times 10^{-6}-5,5 \times 10^{-6}$ & 4.5 & $0-2$ & 8.5 \\
\hline $5.5 \times 10^{-6}-1,0 \times 10^{-5}$ & 5.0 & $2-4$ & 7.5 \\
\hline $1.0 \times 10^{-5}-1,8 \times 10^{-5}$ & 5.5 & $4-6$ & 6.5 \\
\hline $1.8 \times 10^{-5}-3,0 \times 10^{-5}$ & 6.0 & $6-9$ & 5.5 \\
\hline $3.0 \times 10^{-5}-5,0 \times 10^{-5}$ & 6.5 & $9-12$ & 4.5 \\
\hline $5.0 \times 10^{-5}-9,0 \times 10^{-5}$ & 7.0 & $12-15$ & 3.5 \\
\hline $9.0 \times 10^{-5}-1,5 \times 10^{-4}$ & 7.5 & $15-18$ & 2.5 \\
\hline
\end{tabular}




\begin{tabular}{|c|c|c|c|}
\hline Hydraulic Conductivity $(\mathrm{m} / \mathrm{sec})$ & \multicolumn{2}{|c|}{ Gradient of Slope (\%) } \\
\hline Value & Rating & Class & 1.5 \\
\hline $2.0 \times 10^{-4}-3,0 \times 10^{-4}$ & 8.0 & $21-25$ & 1.0 \\
\hline $3.0 \times 10^{-4}-4,5 \times 10^{-4}$ & 8.25 & $25-30$ & \\
\hline $4.5 \times 10^{-4}-6,0 \times 10^{-4}$ & $8 ., 5$ & & \\
\hline $6.0 \times 10^{-4}-1,0 \times 10^{-3}$ & 8.75 & & \\
\hline $1.0 \times 10^{-3}-1,5 \times 10^{-3}$ & 9.0 & & \\
\hline $1.5 \times 10^{-3}-2,5 \times 10^{-3}$ & 9.25 & & \\
\hline $2.5 \times 10^{-3}-4,5 \times 10^{-3}$ & 9.5 & & \\
\hline $4.5 \times 10^{-3}-4,0 \times 10^{-2}$ & 9.75 & & \\
\hline
\end{tabular}

After all variable values and parameter weights from each observation point are determined, the SINTACS index can be determined by calculating the values of each indicator and adding them together.

$$
\mathrm{I}_{\text {SINTACS }}=\sum^{7}{ }_{\mathrm{i}}=\mathrm{Ri} \times \mathrm{Wi}
$$

where ISINTACS is the groundwater vulnerability index, $\mathrm{R}$ is the rating for each parameter and $\mathrm{W}$ is the weight for each parameter as shown in Table 4.

Table 4. Weighting scenarios in SINTACS Method

\begin{tabular}{|l|c|c|c|c|c|c|c|}
\hline Weighting Scenarios & S & I & N & T & A & C & S \\
\hline Normal impact & 5 & 4 & 5 & 3 & 3 & 3 & 3 \\
\hline Relevant impact & 5 & 5 & 4 & 5 & 3 & 2 & 2 \\
\hline $\begin{array}{l}\text { Drainage from } \\
\text { surficial network }\end{array}$ & 4 & 4 & 4 & 2 & 5 & 5 & 2 \\
\hline Karstic impact & 2 & 5 & 1 & 3 & 5 & 5 & 5 \\
\hline Fissuring impact & 3 & 3 & 3 & 4 & 4 & 5 & 4 \\
\hline
\end{tabular}

Source : [14]

Because the study area is a residential and agricultural area, the normal impact scenario is used in this study. Based on this scenario and taking into account weight and rating calculations, groundwater vulnerability in the study area is determined as shown in Table 5.

Table 5. Groundwater vulnerability index

\begin{tabular}{|c|c|}
\hline Interval of Vulnerability Index & Vulnerability Level \\
\hline$<80$ & Very Low \\
\hline $80-<105$ & Low \\
\hline $105-<140$ & Moderate \\
\hline $140-<186$ & Rather High \\
\hline $186-210$ & High \\
\hline$>210$ & Very High \\
\hline
\end{tabular}

Sources : $[14,15]$

\section{Result and discussion}

\subsection{Location}

This study is located in Banguntapan District which is administratively included in the Bantul Regency area (Figure 1). In general, Banguntapan district is in the eastern Yogyakarta groundwater basin and is included in the geomorphological unit at the Merapi Volcano Foot Plain.

Banguntapan District consists of eight villages namely Tamanan, Jagalan, Singosaren, Wirokerten, Jambidan, Potorono, Baturetno, and Banguntapan. The total area of Banguntapan District reaches $28.48 \mathrm{~km}^{2}$ or around $5.62 \%$ of the total area of Bantul Regency. The population in the Banguntapan District according to the records of 2018 was 145956 inhabitants. Banguntapan Village is the village with the largest area and population in Banguntapan Sub-District.

\subsection{Determination of groundwater vulnerability}

SINTACS stands for parameters that can cause groundwater vulnerability to pollution, namely phreatic level, constant infiltration rate, aeration conditions, soil texture, aquifer media, hydraulic conductivity and slope. The depth of the phreatic level affects groundwater vulnerability because the distance between the surface of the soil and the phreatic level will determine the time taken by the pollutant to groundwater, so that it will determine the time of impregnation of the waste and chemical processes during its absorption. The results of measurements in the field show that the groundwater phreatic level in the study area varied considerably from $1.13 \mathrm{~m}$ to $6.40 \mathrm{~m}$, so the rating value ranged from 6.5 to 10 (Table 6).

Table 6. Depth and fluctuations in groundwater level

\begin{tabular}{|l|c|c|}
\hline \multicolumn{1}{|c|}{ Location } & Depth $(\mathrm{m})$ & Rating \\
\hline Banjar, Tamanan & 1.13 & 10.0 \\
\hline Glondong, Wirokerten & 3.10 & 8.5 \\
\hline Jambidan Kidul, Jambidan & 1.97 & 10.0 \\
\hline Kretek Lor, Jambidan & 2.75 & 8.5 \\
\hline Singosaren I, Singosaren & 3.50 & 8.0 \\
\hline Sayangan, Jagalan & 3.95 & 8.0 \\
\hline Potorono, Potorono & 4.00 & 8.0 \\
\hline Plakaran, Baturetno & 2.00 & 9.0 \\
\hline Pelem, Baturetno & 3.10 & 8.5 \\
\hline Maguwo, Banguntapan & 6.40 & 6.5 \\
\hline Wonocatur, Banguntapan & 5.05 & 7.0 \\
\hline Plumbon, Banguntapan & 4.90 & 7.5 \\
\hline
\end{tabular}

Infiltration determines the velocity at which contaminants travel to groundwater. If the infiltration rate is low then the ease of contaminants reaching groundwater is also low. Conversely, if the infiltration rate is high, the ease of contaminants reaching groundwater is also high. Because all soil type of the research area is regosol, constant infiltration was determined based on infiltration measurement data that had been done in some regosol soil in Yogyakarta basin before $[16,17]$. The results show an average infiltration value of $0.545 \mathrm{~cm} /$ minute or $327 \mathrm{~mm} /$ hour, so rating values in all observation wells are 7 . 
Aeration zone is a hydrogeological system that can function as a barrier to pollutants if the stone texture is impermeable. Therefore, clay is given a low rating because it is impervious to be able to withstand pollutants, while sand is given a high rating because of its porous nature. Field observations show that all research areas are composed of sandy textured material, so the rating value is 5.5 .

Soil texture will determine the ease of pollutants in passing through liquids. Sand will be easier to absorb pollutants than clay, so that sand is given a higher rating. The entire study area is composed of clay sand, so the rating value is 6.6.

Aquifer media describe the process that occurs when there is a mixture of pollutants with groundwater. Aquifer media play a role in determining the speed of mixing of pollutants with groundwater. In aquifer media there are also several chemical processes such as dissolution and reaction between pollutants and rocks. It can be said that the aquifer media in the study area is sand so that all the values are 8 .

Hydraulic conductivity is a measure of the ability of rocks to pass through liquids. Rock material with high hydraulic conductivity values will be easier to pass through waste, than those with low values. Therefore, sand will have a high rating value compared to other rock types. The study area is composed of sand material, so that all rating values are 7.5.

The slope gradient plays an important role in the assessment of vulnerability because it will determine the speed of the flow of waste at the ground surface. If the slope is steep, the waste will flow quickly and little will seep into the ground. Conversely, if the slope is flat, the flow velocity at the ground surface will be low and the waste has many opportunities to seep. Therefore, steep places are given a low rating, while ramps are given a high rating. The topography in the study area is flat, so that all rating ratings are 9.5 .

\subsection{SINTACS index analysis}

Because the effect of each of the parameters related to pollution is not the same, the weights are also not the same. For normal impact scenarios, the phreatic surface depth parameters are weighted 5 , constant infiltration is weighted 4 , the aeration condition is given weight 5 , soil texture is given weight 3 , aquifer media are given weight
3 , hydraulic conductivity is given weight 3 and slope weight is weighted 3 .

Furthermore, based on the rating of each parameter and its weight, groundwater vulnerability index can be calculated for each measurement and observation location (Table 7). The results of calculations at 12 measurement and observation locations show variations in groundwater vulnerability index values from 182.8 to 200.3. Judging from the level of vulnerability, 10 locations are classified as high levels of vulnerability and 2 locations are classified as quite high levels of vulnerability (Figure 1).

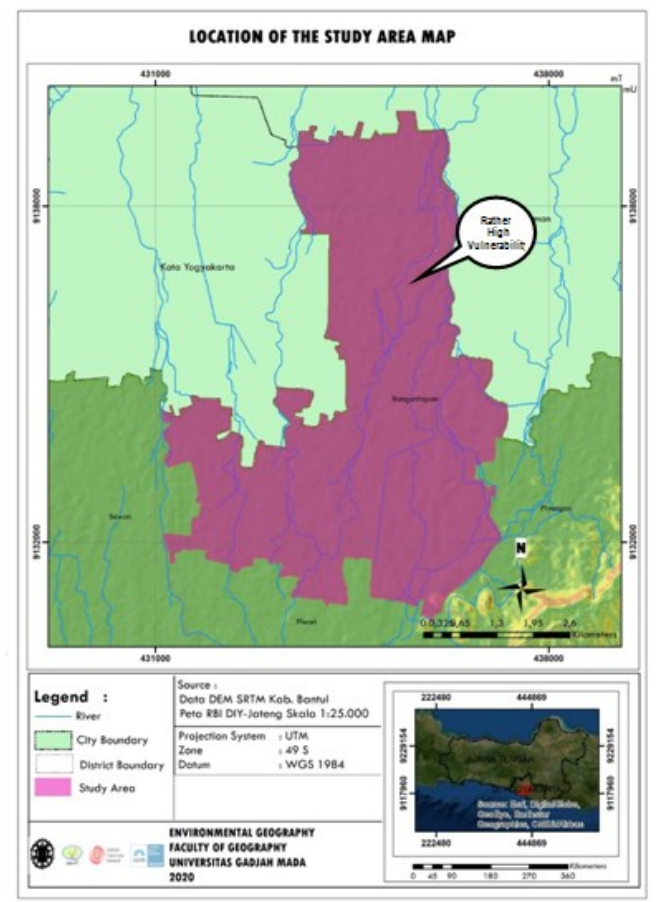

Fig. 1. Study location

From Table 7 and Figure 1, it can be seen that most of the study areas are classified as high levels of vulnerability. The level of vulnerability is rather high only in 2 observation wells in Maguwo and Wonocatur, both of which are in the village of Banguntapan. Noting this, it appears that differences in groundwater vulnerability in the study area are more determined by groundwater depth.

Table 7. Weighted SINTACS parameter values (normal impact)

\begin{tabular}{|c|c|c|c|c|c|c|c|c|c|}
\hline No & $\begin{array}{c}\text { S } \\
\text { (weight 5) }\end{array}$ & $\begin{array}{c}\text { I } \\
\text { (weight 4) }\end{array}$ & $\begin{array}{c}\text { N } \\
\text { (weight 5) }\end{array}$ & $\begin{array}{c}\text { T } \\
\text { (weight 3) }\end{array}$ & $\begin{array}{c}\text { A } \\
\text { (weight 3) }\end{array}$ & $\begin{array}{c}\text { C } \\
\text { (weight 3) }\end{array}$ & $\begin{array}{c}\text { S } \\
\text { (weight 3) }\end{array}$ & $\begin{array}{c}\text { Vulnerability } \\
\text { Index }\end{array}$ & $\begin{array}{c}\text { Vulnerability } \\
\text { Level }\end{array}$ \\
\hline 1 & 50 & 28 & 27.5 & 19.8 & 24 & 22.5 & 28.5 & 200.3 \\
\hline 2 & 42.5 & 28 & 27.5 & 19.8 & 24 & 22.5 & 28.5 & 192.8 \\
\hline 3 & 50 & 28 & 27.5 & 19.8 & 24 & 22.5 & 28.5 & 200.3 \\
\hline 4 & 42.5 & 28 & 27.5 & 19.8 & 24 & 22.5 & 28.5 & 192.8 & High \\
\hline 5 & 40 & 28 & 27.5 & 19.8 & 24 & 22.5 & 28.5 & 190.3 \\
\hline 6 & 40 & 28 & 27.5 & 19.8 & 24 & 22.5 & 28.5 & 190.3 \\
\hline 7 & 40 & 28 & 27.5 & 19.8 & 24 & 22.5 & 28.5 & 190.3 \\
\hline 8 & 45 & 28 & 27.5 & 19.8 & 24 & 22.5 & 28.5 & High & High \\
\hline 9 & 42.5 & 28 & 27.5 & 19.5 & 24 & 22.5 & 28.5 & 195.3 \\
\hline 10 & 32,5 & 28 & 27.5 & 19.8 & 24 & 22.5 & 28.5 & High \\
\hline 11 & 35 & 28 & 27.5 & 19.8 & 24 & 22.5 & 28.5 & High \\
\hline 12 & 37.5 & 28 & 27.5 & 19.8 & 24 & 22.5 & 28.5 & 182.8 \\
\hline
\end{tabular}




\section{Conclusion}

The variation of groundwater vulnerability index values in the study area ranged from 182.8 to 200.3 , with 10 locations classified as high vulnerability and 2 locations classified as rather high vulnerability.

Because it is located in a similar geological condition that is Aquifer Unit of the Merapi Volcanic Fluvio Plain where most of the constituent material of this aquifer is sand and a little clay as inserts, the difference in groundwater vulnerability to pollution in the study area is only determined by the difference in groundwater depth.

This paper is part of a study entitled "Groundwater Vulnerability Study Using SINTACS Method in Banguntapan District, Bantul Regency", financed by Final Assignment Recognition (Rekognisi Tugas Akhir/RTA) Programme Universitas Gadjah Mada year 2020.

\section{References}

1. K. Knodel, K. Lange, V.H. Jurgen, Environmental Geology: Handbook of Field Methods and Case Studies (2007).

2. N. Kazakis, K. Voudouris, Journal Hydrology 525:13-25 (2015).

3. E. Costudio, Trends in Groundwater Pollution : Loss of Groundwater Quality and Related Services. Thematic Paper of Groundwater Governance. Dept. of Geo-Engineering and International Centre for Groundwater Hydrology, Technical University of Catalonia, Barcelona (2011).

4. M. Sinan, M. Razack. Journal of Environment Geology 57:349-363 (2008).

5. L. Aller, T. Bennet, I.H. Lehr, R.J. Petty, G. Hackett, DRASTIC: A Standardized System For Evaluating Ground Water Pollution Potential Using Hydrogeologic Settings. EPA 600/2-87-035 (1987).

6. R. Gogu, A. Dassargues. Hydrogeoly J., 8,3:337345 (2000).

7. Badan Pusat Statistik Kabupaten Bantul. Kecamatan Banguntapan Dalam Angka Tahun 2011-2019. Badan Pusat Statistik, Yogyakarta (2019). [In Bahasa Indonesia].

8. F. Worrali, D.W. Kolpin, J. Hydrol. 293,1-4:191204 (2004.)

9. J. Vrba, A. Zaporozec, Guidebook on mapping groundwater vulnerability, International Association of Hydrogeologists (International Contribution to Hydrogeology 16). Heinz Heise, Hannover, (1994).

10. M. Civita, Journal of Water Resources and Protection, 2:14-28 (2010).

11. H. Al-Amoush, N.A. Hammouri, F. Zunic, E. Salameh, Water Resources Management 24:34613485 (2010).

12. J. Majandang, S. Sarapirome, Environ. Earth Sci., 68:2025-2039(2013).

13. R. Lee, Hidrologi Hutan. Gadjah Mada University Press, Yogyakarta (1990). [in Bahasa Indonesia]
14. M. Civita, M. De Mai, Geofisica Internacional, 43: 513-532 (2004).

15. M. Al-Kuisi, A. El-Naqa, N. Hammouri, Jordan. Environ. Geol., 50: 651-667 (2006).

16. S. Suprayogi, Respon sifat tanah terhadap hujan (kajian tentang infiltrasi dan permeabilitas) di wilayah Kabupaten Sleman, Yogyakarta. Laporan Penelitian, Yogyakarta (1996). [in Bahasa Indonesia].

17. S. Purnama, Water infiltration into soil and its effect to surface runoff in subdistrict of Kasihan, Bantul regency. In: Proceeding of The $1^{\text {st }}$ International Conference on Geography and Education (ICGE 2016). Advances in Social Science, Education and Humanities Research, 79:87-91 (2017). 